\title{
TNI ANGKATAN LAUT SEBAGAI PENEGAK HUKUM DAN SEKALIGUS PENYIDIK TINDAK PIDANA DI LAUT
}

\author{
Oleh : \\ Mangisi Simanjuntak \\ Dosen di Fakultas Hukum Universitas Dirgantara Marsekal Suryadarma Jakarta Timur \\ dan Dosen di Fakultas Hukum UKI Jakarta serta \\ Candidate Doktor Universitas Borobudur Jakarta Timur \\ Email : (simanjuntakmangisi1@gmail.com)
}

\begin{abstract}
Abstrak :
TNI AL, selain sebagai penegak hukum di laut juga sebagai penyidik tindak pidana di laut. Kewenangan sebagai penyidik tindak pidana tidak dimiliki oleh matra lain bahkan seluruh Tentara di dunia hanya TNI AL lah yang mempunyai kewenangan sebagai penyidik. Kewenangan yang dimiliki oleh TNI AL selain berdasarkan undang-undang/ hukum nasional juga didasarkan oleh hukum internasional dalam hal ini Konvensi PBB Tentang Hukum Laut 1982 (United Convention On The Law Of The Sea 1982/ Unclos 1982).
\end{abstract}

Kata kunci : TNI AL sebagai penyidik tindak pidana di laut.

\section{PENDAHULUAN}

\section{A. Latar Belakang Permasalahan}

Undang-Undang Nomor 34 Tahun 2004 tentang Tentara Nasional Indonesia (TNI), khususnya pada pasal 9 telah diatur tentang peran dan fungsi serta tugas Tentara Nasional Indonesia Angkatan Laut (TNI AL) yang dapat digolongkan sebagai fungsi militer, fungsi polisionil dan fungsi di plomasi. Adapun peran dan fungsi militernya dinyatakan pada pasal 9 huruf a yaitu Angkatan Laut bertugas melaksanakan tugas TNI matra laut di bidang pertahanan, peran dan fungsi polisionil dinyatakan pada pasal 9 huruf $b$, sedangkan peran dan fungsi diplomasinya dinyatakan pada pasal 9 huruf c yaitu Angkatan Laut bertugas melaksanakan tugas diplomasi dalam rangka mendukung kebijakan politik luar negeri yang ditetapkan oleh pemerintah. ${ }^{1}$

Untuk peran dan fungsi TNI AL bidang polisionil yang dinyatakan pada pasal 9 huruf $b$ tersebut di atas yaitu bahwa Angkatan Laut bertugas menegakan hukum dan menjaga keamanan di wilayah laut yurisdiksi nasional sesuai dengan ketentuan hukum nasional dan hukum internasional yang telah diratifikasi. Penjelasan pasal 9 huruf $b$ dinyatakan bahwa yang dimaksud dengan

\footnotetext{
${ }^{1}$. Republik Indonesia, Undang-Undang Nomor 34 Tahun 2004 tentang Tentara Nasional Indonesia, pasal 9
} 
menegakkan hukum dan menjaga keamanan adalah segala bentuk kegiatan yang berhubungan dengan penegakan hukum di laut sesuai dengan kewenangan TNI AL (constabulary function) yang berlaku secara universal dan sesuai dengan ketentuan perundang-undangan yang berlaku untuk mengatasi ancaman tindakan kekerasan, ancaman navigasi, serta pelanggaran hukum di wilayah laut yurisdiksi nasional. Menegakan hukum yang dilaksanakan oleh TNI AL di laut, terbatas dalam lingkup pengejaran, penangkapan, penyelidikan, dan penyidikan perkara yang selanjutnya diserahkan kepada Kejaksaan. TNI AL tidak menyelenggarakan pengadilan. ${ }^{2}$

Dari penjelasan tersebut di atas, dapat diketahui bahwa TNI AL, selain sebagai penegak hukum di laut juga sebagai penyidik tindak pidana di laut. Kewenangan sebagai penyidik tindak pidana tidak dimiliki oleh matra lain bahkan seluruh Tentara di dunia hanya TNI AL lah yang mempunyai kewenangan sebagai penyidik. Kewenangan yang dimiliki oleh TNI AL selain berdasarkan undangundang/ hukum nasional juga didasarkan oleh hukum internasional dalam hal ini Konvensi PBB Tentang Hukum Laut 1982 (United Convention On The Law Of The Sea 1982/ Unclos 1982). Salah satu kewenangan tersebut terdapat pada pasal 7 Unclos 1982 tentang "Kapal (Perang) atau pesawat udara (tempur) yang berhak menyita karena perompakan, penyitaan merupakan bagian kewenangan penyidik.

${ }^{2}$. Republik Indonesia, Undang-Undang Nomor 34 Tahun 2004 tentang Tentara Nasional Indonesia pasal 9 huruf $\mathrm{b}$ dan penjelasannya.
Tugas dan kewenangan pengejaran, penangkapan, penyelidikan, dan penyidikan perkara seperti halnya penahanan, penyitaan sampai membuat berkas perkara berdasarkan hukum acara yang berlaklu yang selanjutnya diserahkan kepada Kejaksaan tersebut selama ini telah dilaksanakan oleh TNI AL. Standard Operasi dan Prosedure (SOP) dalam melaksanakan tugas dan kewenangan tersebut sudah ada dan diatur dalam SOP TNI AL dalam Peraturan Kepala Staf TNI-AL Nomor 32/V/2009 Tanggal 4 Mei 2009.

Hukum/ undang-undang nasional juga telah mengatur tugas dan kewenangan TNI AL tersebut, khususnya sebagai penegak hukum dan penyidik tindak pidana tertentu di laut. Tindak pidana tertentu dimaksudkan adalah tindak pidana yang ditentukan oleh undang-undang diberikan kewenangan kepada TNI $\mathrm{AL}$ untuk melakukan penegakan hukum dan penyidikan. Adapun tindak pidana tertentu tersebut adalah tindak pidana perompakan, tindak pidana yang terjadi di Zona Ekonomi Eksklusif Indonesia (ZEE Indonesia), tindak pidana perikanan, tindak pidana pelayaran dan tindak pidana pelanggaran wilayah.

Dalam melakukan penegakan hukum dan penyidikan terhadap tindak pidana tertentu di laut ada kendala dan hambatan yang ditemui misalnya keterbatasan sarana dan prasarana, belum satu persepsinya aparat penengak hukum, belum adanya anggaran untuk uang makan tahanan serta biaya/ anggaran penyidikan yang berakibat penegakan hukum dan penyidikan tersebut tidak dapat dilakukan secara optimal. Kendala 
dan hambatan tersebut harus diselesaikan dan dicarikan solusinya agar penegakan hukum dan penyidikan terhadap tindak pidana tertentu di laut dapat dilaksanakan dengan baik serta negara tidak begitu banyak dirugikan akibat terjadinya tindak pidana di laut Indonesia.

\section{B. Rumusan Masalah}

Dasar hukum kewenangan TNI AL melakukan penegakan hukum dan sekaligus melakukakan penyidikan terhadap tindak pidana tertentu serta menyerahkan berkas perkara ke Kejaksaan banyak yang belum mengetahuinya, padahal TNI AL sudah melakukan penyidikan tersebut sejak dikeluarkannya Undang-Undang Nomor 5 Tahun 1983 tentang Zona Ekonomi Eksklusif Indonesia bahkan jauh sebelum tahun 1983 yaitu sejak adanya penangkapan pelaku tindak pidana perompakan di laut. Peran TNI AL sudah tidak diragukan lagi dalam penegakan nhukum di laut walaupun dalam melaksanakan perannya tersebut masih terdapat kendala dan tantangan-tantangan.

Dari latar belakang dan penjelasan di atas dapat dirumuskan beberapa rumusan masalah :

1. Apakah dasar hukum TNI Angkatan Laut sebagai penegak hukum dan penyidik tindak pidana tertentu di laut?

2. Bagaimana upaya TNI Angkatan Laut dalam menghadapi kendala dan tantangan dalam penegakan hukum dan penyidikan tindak pidana di laut.

\section{Tujuan Penulisan :}

1. Sebagai sarana bagi penulis agar kewenangan TNI AL sebagi penyidik khususnya penyidik tindak pidana di laut dapat diperluas melalui pembuatan undang-undang yang baru.

2. Sebagai masukan bagi Pemerintah dan Dewan Perwakilan Rakyat agar anggaran yang terkait dengan tugas TNI AL sebagai penyidik tindak pidana di laut dapat dianggarkan.

\section{PEMBAHASAN}

A. Tindak Pidana Tertentu di Laut dan Dasar Hukum TNI AL sebagai Penegak Hukum dan Penyidiknya.

\section{Beberapa Tindak Pidana Tertentu} di Laut TNI AL Sebagai Penyidiknya:

a. Tindak Pidana Pembajakan/ Perompakan :

Tindak pidana pembajakan/ perompakan sebagaimana dinyatakan dalam Bab XXIX terutama pasal $438 \mathrm{~s} / \mathrm{d}$ pasal 440 KUHP adalah merupakan kejahatan pelayaran yang pada umunya dilakukan karena adanya keinginan untuk mendapatkan materi dari hasil pembajakan/ perompakan tersebut. Kejahatan pembajakan di laut ini di lakukan di laut suatu negara yang merdeka (negara tidak sedang dijajah). ${ }^{3}$

${ }^{3}$. R. Soesilo, Kitab Undang-Undang Hukum Pidana (KUHP) Serta Komenta--Komentarnya Lengkap Pasal Demi Pasal, (Sukabumi : Politea Bogor, 1988) hal 295. 
b. Tindak Pidana di ZEE Indonesia.

Berdasarkan Undang-Undang Nomor 5 Tahun 1983 tentang Zona Ekonomi Eksklusif Indonesia, Tindak Pidana di ZEE Indonesia yaitu diatur pada pasal 5 dinyatakan: barang siapa melakukan eksplorasi dan/atau eksploitasi ekonomis seperti pembangkitan tenaga dari air, arus dan angina di zona ekonomi eksklusif, melakukan eksplorasi dan/atau eksploitasi sumber daya alam hayati yang dilakukan tanpa izin pemerintah Indonesia. Pasal 6 barang siapa membuat dan / atau menggunakan pulau-pulau buatan atau instalasi-instalasi atau bangunan-bangunan lainnya di Zona Ekonomi Eksklusif Indonesia tanpa izin pemerintah Indonesia. Pasal 7 dinyatakan barang siapa melakukan kegiatan penelitian ilmiah di ZEE Indonesia tanpa izin pemerintah Indonesia .

\section{c. Tindak Pidana Perikanan}

Berdasarkan Undang-Undang Nomor 31 Tahun 2004 tentang Perikanan dan juga berdasarkan Undang-Undang Nomor 45 Tahun 2009 tentang Perubahan Undang-Undang Nomor 31 Tahun 2004 tentang Perikanan dinyatakan bahwa tindak pidana perikanan adalah semua kegiatan yang berhubungan dengan penangkapan ikan, pengelolaan dan pemanfaatan sumber daya ikan dan lingkungannya mulai dari praproduksi, produksi, pengolahan sampai dengan pemasaran yang dilaksanakan dalam suatu sistem bisnis perikanan yang tidak memiliki ijin dari pemerintah Indonesia atau melanggar ketentuan dalam ijin tersebut.

\section{d. Tindak Pidana Pelayaran.}

Berdasarkan Undang-Undang Nomor 17 Tahun 2008 tentang Pelayaran sebagaimana dinyatakan dalam Bab XIX Ketentuan Pidana pada pasal $284 \mathrm{~s} / \mathrm{d}$ pasal 336 pada intinya melakukan kegiatan pelayaran tanpa dilengkapi Surat Ijin Berlayar (SIB) atau melakukan kegiatan berlayar tetapi tidak sesuai dengan ijin yang telah diberikan dalam SIB nya.

\section{e. Tindak Pidana Pelanggaran Wilayah}

Berdasarkan pasal 12 ayat (1) huruf $\mathrm{h}$ Ordonansi (UndangUndang) Lautan Territoor (Maritim) 1939 Territorial ZEE en Maritime Kringen Ordonantie 1939 (TZMKO 1939), tindak pidana pelanggaran wilayah dinyatakan bahwa barang siapa, yang tanpa berhak untuk itu seperti tercantum pasal 10 dan 11 (nahkoda kapal-kapal, tongkang-tongkang yang mengibarkan bendera asing), berlabuh atau tinggal mengambang dengan kapal atau tongkangnya dalam lingkaran maritime atau daerah laut Negara Republik Indonesia. Kalau hanya melintas, apalagi lintas damai (innocence passage) di laut territorial bukan 
TNI Angkatan Laut Sebagai Penegak Hukum Dan Sekaligus Penyidik

merupakan pelanggaran

wilayah.

2. Dasar Hukum TNI AL sebagai Penyidik Tindak Pidana Tertentu.

a. Penyidik Tindak Pidana Pembajakan/ perompakan :

TNI AL adalah penegak hukum sekaligus sebagai penyidik tindak pidana pembajakan/perompakan yang terjadi di laut territorial Indonesia dan juga sebagai penyidik tindak pidana pembajakan/perompakan terhadap kapal berbendera Indonesia yang terjadi di luar laut territorial Indonesia. Dasar hukum kewenangan TNI AL tersebut diatur dalam pasal 13 Ordonansi (Undang-Undang) Lautan Territoor (Maritim) 1939 Territorial ZEE en Maritime Kringen Ordonantie 1939 (TZMKO 1939) yang menyatakan bahwa untuk memelihara dan mengawasi pentaatan ketentuan-ketentuan dalam ordonansi ini ditugaskan kepada : Komandan Angkatan Laut Surabaya, KomandanKomandan kapal-kapal perang Negara dank amp-kamp penerbangan dari Angkatan Laut Nahkoda-Nahkoda dari Jawatan Pelayaran Negara dan Nahkoda-nahkoda dari kapalkapal Perambuan (Bebakening) dan penerangan pantai, orangorang yang dibawah perintah Perwira - perwira Angkatan Laut yang diserahi tugas pimpinan atas kapal daerah, Syahbandar dan pegawaipegawai yang bertugas semacam itu, Pandu-pandu laut (Loodsen), pula juragan-juragan dari kapal daerah dan selanjutnya orang-orang yang ditunjuk oleh Kepala Staf Angkatan Laut.

Hukum Acara yang digukanan dalam melakukan penegakan hukum tindak pidana permbajakan/ perompakan ini, sebagaimana diatur dalam Undang-Undang Nomor 8 Tahun 1981 tentang Kitab Undang-Undang Hukum Acara Pidana (KUHAP), karena tindak pidana perompakan di atur dan ditentukan pada pasal 438-450 KUHP. ${ }^{4}$ Kewenangan penyidikan yang dilakukan instansi lain diatur dalam pasal 284 ayat (2) Peraturan Pemerintah Nomor 27 Tahun 1983 tentang Pelaksanaan KUHAP yang mengakui adanya instansi lainsebagai penyidik selain Polri.

b. Penyidik Tindak Pidana di ZEE Indonesia.

Dasar hukum TNI AL sebagai penegak hukum dan penyidik tindak pidana yang terjadi di ZEE Indonesia adalah pasal 14 ayat (1) Undang-Undang Nomor 5 Tahun 1983 tentang Zona Ekonomi Eksklusif Indonesia yang menyatakan :

"Aparatur penegak hukum di bidang penyidikan di Zona Ekonomi Eksklusif Indonesia adalah Perwira Tentara

4 . M. Karjadi dan R.Soesilo, Kitab UndangUndang Hukum Acara Pidana dengan penjelasan dan Komentar (Bogor : Politea Bogor 1983) hal 25- 63. 
Nasional Indonesia Angkatan Laut yang ditunjuk oleh Panglima Angkatan Bersenjata Republik Indonesia".

Panglima Angkatan Bersenjata Republik Indonesia yang dimaksud adalah Panglima Tentara Nasional Indonesia (Panglima TNI).

Yang dimaksud dengan Perwira Tentara Nasional Indonesia Angkatan Laut yang dapat ditunjuk (yang disumpah sebagai penyidik) sebagai penyidik adalah misalnya Komandan Kapal, Panglima Daerah Angkatan Laut, Komandan Pangkalan dan Komanda Stasion Angkatan Laut. Penetapan Perwira Tentara Nasional Indonesia Angkatan Laut sebagai aparat penyidik di Zona Ekonomi Eksklusif Indonesia sesuai dengan pasal 17 Peraturan Pemerintah Nomor 27 Tahun 1983 tentang Pelaksanaan Undang-Undang Nomor 8 Tahun 1981 tentang Kitab Undang-Undang Hukum Acara Pidana (KUHAP). ${ }^{5}$

Dalam rangka melaksanakan hak berdaulat, hak-hak lain yurisdiksi dan kerwajibankewajibannya, aparat penegak hukum Republik Indonesia yang berwenang, dapat mengambil tindkan-tindakan hukum sesuai dengan UndangUndang Nomor 8 Tahun 1981 tentang Kitab Undang-Undang Nomor 8 Tahun 1981 tentang Kitab Undang-Undang Hukum Acara Pidana tersebut diatas dengan pengecualian sebagai berikut :

1) Penangkapan terhadap kapal dan/atau orang-orang yang diduga melakukan pelanggaran di ZEE Indonesia meliputi penghentian kapal sampai dengan diserahkannya kapal dan/atau orang-orang tersebut di pelabuhan di mana perkara tersebut dapat diproses lebih lanjut;

2) Penyerahan kapal dan/atau orang-orang tersebut harus dilakukan secepat mungkin dan tidak boleh melebihi jangka waktu 7 (tujuh) hari, kecuali apabila terdapat force majeure; ${ }^{6}$

\section{c. Penyidik Tindak Pidana Perikanan}

Dasar hukum TNI AL sebagai penegak hukum dan penyidik tindak pidana Perikanan adalah pasal 73 ayat (1) UndangUndang Nomor 31 Tahun 2004 tentang Perikanan yang menyatakan :

"Penyidik tindak pidana di bidang perikanan dilakukan oleh Penyidik Pegawai Negeri Sipil Perikanan, Perwira TNI AL, dan Pejabat Polisi Negara Republik Indonesia"

Kewenangan TNI AL sebagai penyidik Perikanan tersebut 
diperkuat lagi dengan undangundang Perikanan yang baru yaitu pasal 73 ayat (1) UndangUndang Nomor 45 Tahun 2009 tentang Perubahan UndangUndang Nomor 31 Tahun 2004 tentang Perikanan yang menyatakan :

"Penyidikan tindak pidana di bidang perikanan di wilayah pengelolaan perikanan Negara Republik Indonesia dilakukan oleh Penyidik Pegawai Negeri Sipil Perikanan, Penyidik Perwira TNI AL, dan/atau Penyidik Kepolisian Negara Republik Indonesia".

Untuk perkara perikanan, walaupun mempunyai pengadilan sendiri, tetapi hukum acara yang dperigunakan tetap mengacu pada Kitab Undang-Undang Hukum Acara Pidana (KUHAP).Dalam pasal 72 Undang-Undang Nomor 31 Tahun 2004 tentang Perikanan dinyatakan bahwa penyidikan dalam perkara tindak pidana perikanan dilakukan berdasarkan hukum acara yang berlaku (KUHAP), kecuali ditentukan lain dalam undangundang ini. ${ }^{7}$

\section{d. Penyidik Tindak Pidana Pelayaran.}

Dalam tindak pidana yang terjadi di bidang Pelayaran, kewenangan TNI AL melakukan penegakan hukum

7. H. Supriadi dan Alimuddin, Hukum Perikanan di Indonesia ( Pali: Simar Grafika 2011), hal 430-431. dan sebagai penyidik diatur pada pasal 282 dan penjelasannya Undang-Undang Nomor 17 Tahun 2008 tentang Pelayaran. Pasal 282 menyatakan :

"Selain penyidik pejabat polisi Negara Republik Indonesia dan penyidik lainnya, pejabat pegawai negeri sipil tertentu di lingkungan instansi yang lingkup tugas dan tanggung jawabnya di bidang pelayaran diberi wewenang khusus sebagai penyidik sebagaimana dimaksud dalam Undang-Undang ini“"

Yang dimaksud dengan "penyidik lainnya" adalah penyidik sesuai dengan ketentuan peraturan perundangundangan, antar lain Perwira Tentara Nasional Indonesia Angkatan Laut.

Hukum acara yang dipergunakan dalam tindak pidana pelayaran adalah hukum acara yang diatur dalam KUHAP

\section{e. Penyidik Tindak Pidana Pelanggaran Wilayah}

Dasar hukum TNI AL sebagai penyidik tindak pidana pelanggaran wilayah masih menggunakan pasal 13 Ordonansi (Undang-Undang) Lautan Territoor (Maritim) 1939 Territorial ZEE en Maritime Kringen Ordonantie 1939 (TZMKO 1939) karena ketentuan tindak pidana pelanggaran wilayah diatur dalam Ordonansi (Undang- 
Undang) Lautan Territoor (Maritim) 1939 Territorial ZEE en Maritime Kringen Ordonantie 1939 (TZMKO 1939 yaitu pasal 12 ayat (1) huruf h.

Meskipun tindak pidana pelanggaran wilayah diatur dalam pasal 12 ayat (1) huruf $h$ TZMKO tetapi hukum acara yang dipergunakan dalam melakukan penyidikan tindak pidana pelanggaran wilayah ini adalah hukum acara sebagaimana yang diatur dan ditentukan dalam Kitab Undang-Undang Hukum Acara Pidana (KUHAP)

\section{B. Upaya TNI AL menghadapi kendala dalam melakukan penyidikan tindak pidana di laut.}

Dalam melakukan penyidikan terhadap tindak pidana di laut, ada beberapa kendala yang dihadapi oleh penyidik TNI AL yaitu sebagai berikut :

\section{Beberapa instansi terkait di wilayah tertentu belum mengetahui dan belum mau menerima kewenangan TNI AL sebagai penyidik tindak pidana di laut.}

Kewenangan TNI AL sebagai penyidik tindak pidana di laut belum sepenuhnya diketahui oleh aparat instansi penegak hukum terkait seperti halnya Kejaksaan. Aparat dari instansi tersebut di beberapa wilayah bahkan masih ada yang belum mau menerima bahwa TNI AL sebagai penyidik tindak pidana di laut khususnya tindak pidana perompakan. Pasal 13 Ordonansi (Undang-Undang) Lautan Territoor (Maritim) 1939 Territorial ZEE en Maritime Kringen Ordonantie 1939 (TZMKO 1939), menurut instansi tersebut di beberapa tidak dapat digunakan sebagai dasar hukum TNI AL sebagai penyidik tindak pidana perompakan, karena Ordonansi (Undang-Undang) tersebut masih merupakan produk hukum Belanda dan juga sudah kadaluarsa.

Menyikapi keraguan tersebut di atas, TNI AL memberikan jawaban secara legalitas bahwa TZMKO 1939 tersebut walaupun produk hukum Belanda tetapi undang-undang Indonesia belum pernah mencabutnya. Bukankah Undang-Undang Nomor 1 Tahun 1946 tentang Kitab UndangUndang Hukum Pidana (KUHP) yang nama aslinya Wetboek van strafrecht masih merupakan produk Belanda dan bahkan mulai berlaku di Indonesia sejak Januari tahun $1917^{8}$. KUHP tersebut sampai saat ini berlaku dan menjadi hukum positif di negara Indonesia. ${ }^{9}$

Upaya TNI AL menghadapi kendala seperti ini biasanya dilakukan koordinasi dan sosialisasi. Koordinasi dilakukan dengan cara menjelaskan dan menunjukan berkas perkara penyidikan tindak pidana

${ }^{8}$. Neng Djubaedah, Undang=-Undang Nomor 44 Tahun 2008 tentang Pornografi, Perspektif Negara Hukum Berdasarkan Pancasila, (Jakarta : Sinar Grafika, 2011) hal 3

9. Djoko Prakoso, Pembaharuan Hukum Pidana di Indonesia ( Yogyakarta : Penerbit LIBERTY, 1987) hal 4. 
perompakan yang sudah diterima dan dinyatakan lengkap (P-21) oleh pihak Kejaksaan Negeri di wilayah lain, bahkan menjelaskan perkara yang sudah sampai penyerahan tersangka dan barang bukti (Tahap II) dari pihak TNI AL kepada pihak Kejaksaan Negeri. Apabila penjelasan dan koordinasi seperti ini dianggap kurang menyakinkan pihak Kejaksaan Negeri di wilayah tertentu, maka penyidik TNI AL dapat menunjukan putusan pengadilan yang sudah berkekuatan hukum tetap terhadap perkara perompakan yang TNI AL sebagai penyidiknya.

Sosialisasi yang dilakukan oleh TNI AL kepada masyarakat dan instansi terkait dengan berbagai macam cara, salah satu caranya adalah menerbitkan dan mengedarkan pamplet, menulis tentang kewenangan TNI AL sebagai penegak hukum sekaligus dasar hukum TNI AL sebagai penyidik tindak pidana di laut, melakukan penyuluhan hukum bahkan sampai mengadakan kerjasama dengan instansi terkait tentang prosedur penanganan tindak pidana di laut. Dalam mensosialisasikan kewenangan penyidik TNI AL tersebut tak kalah pentingnya adanya kerjasama antara Kejaksaan dan TNI AL atau dengan instansi lain agar para aparatur Kejaksaan dan instansi lain yang baru direkrut mengetahui dan mempelajari kewenangan TNI AL sebagai penyidik tindak pidana di laut terutama tindak pidana perompakan dan tindak pidana lainnya.
Berbeda dengan tindak pidana perikanan yang sudah jelas menyatakan bahwa TNI AL adalah penyidik tindak pidana perikanan di dalam pasal 73 Undang-Undang Nomor 31 Tahun 2004 tentang Perikanan, undangundang tersebut merupakan produk hukum nasional yang dihasilkan oleh lembaga eksekutif dan legislative setelah Indonesia memperoleh kemerdekaannya.

2. Belum adanya biaya penyidikan, uang makan dan rumah tahanan pelaku tindak pidana di laut serta anggaran untuk juru bahasa.

Kendala lain bagi TNI AL dalam melakukan penyidikan tindak pidana di laut adalah belum adanya anggaran untuk biaya penyidikan dan uang makan para tahanan pelaku tindak pidana di laut, anggaran untuk juru bahasa dari negara asing, karena anak buah kapal yang ditangkap biasanya banyak dari negara lain yang tidak bisa berbahasa Indonesia, anggaran untuk biaya kesehatan atau biaya pemakamam apabila ada tahanan yang meninggal dunia. Adapun biayabiaya tersebut di atas untuk sementara ini diambil dari anggaran operasi dan latihan TNI AL.

Biaya penyidikan biasanya digunakan untuk biaya kertas dan alat tulis lainnya dalam pembuatan berkas perkara, sedangkan uang makan para tahanan digunakan untuk biaya keperluaan makan dan lainnya bagi para tahanan. Biaya juru bahasa biasanya digunakan 
untuk honor para penterjemah selama pemeriksaan para tersangka dan para saksi yang berkewargaan negara asing.

Rumah tahanan Negara (Rutan) yang menjadi tempat tahanan pelaku tindak pidana di laut juga belum dimiliki oleh penyidik TNI AL. Biasanya para tahanan dititipkan di rumah tahanan Polisi Militer atau rumah tahanan negara yang dibawah binaan Kejakasaan.

Yang paling penting dari anggaran tersebut di atas adalah anggaran biaya kesehatan dan anggran untuk biaya penguburan bagi tahanan apabila ada yang meninggal, karena pernah ada tahanan yang sakit kemudian meninggal dunia terpaksa harus dimakamkan di Indonesia karena tidak ada satu negara pun mau mengakui tahanan tersebut sebagai warga negaranya.

\section{PENUTUP}

\section{A. Kesimpulan}

Dari penjelasan atau pembahasan tersebut di atas dapat disimpulkan sebagai berikut :

1. TNI AL selain sebagai penegak hukum juga sebagai penyidik terhadap tindak pidana tertentu di laut berdasarkan undang-undang yang telah ditentukan.

2. Dalam melakukan penyidikan terhadap tindak pidana di laut, masih ada kendala-kendala yang dihadapi, misalnya anggaran penyidikan, uang makan tahanan, honor untuk juru bahasa, biaya kesehatan serta rumah tahanan negara untuk para tersangka.

\section{B. Saran}

Berdasarkan kesimpulan di atas, maka dapat disarankan sebagai berikut :

1. Agar pemerintah dan DPR memperluas kewenangan TNI AL sebagai penyidik tindak pidana di laut.

2. Agar pemerintah bersama-sama dengan DPR menganggarkan biaya-biaya dalam APBN untuk penyidikan yang dilakukan oleh TNI AL terhadap tindak pidana di laut .

\section{DAFTAR PUSTAKA}

Antonius Cahyadi (2010), Pengantar ke Filsafat Hukum, Jakarta : Kencana Prenada Media Group.

Djoko Prakoso, (1987), Pembaharuan Hukum Pidana di Indonesia, Yogyakarta : LIBERTY, 1987).

H. Supriadi dan Alimuddin (2011), Hukum Perikanan di Indonesia , Palu: Sinar Grafika .

I Made Pasek Diantha (2002), Zona Ekonomi Eksklusif Indonesia, Berdasarkan Konvensi Hukum Laut PBB 1982, Bandung : Mandar Maju.

M. Karjadi dan R.Soesilo (1993), Kitab Undang-Undang Hukum Acara Pidana dengan penjelasan dan Komentar , Bogor : Politea Bogor

Neng Djubaedah (2011), UndangUndang Nomor 44 Tahun 2008 tentang Pornografi, Perspektif Negara Hukum Berdasarkan Pancasila, Jakarta : Sinar Grafika. 
TNI Angkatan Laut Sebagai Penegak Hukum Dan Sekaligus Penyidik Tindak Pidana Di Laut

Nunung Mahmudah (2015), Illegal

Fishing, Pertanggungjawaban

Pidana Korporasi di Wilayah

Peariran Indonesia, Jakarta :

Sinar Grafika.

R. Soesilo(1988), Kitab Undang-

Undang Hukum Pidana

(KUHP) Serta Komenta--

Komentarnya Lengkap Pasal

Demi Pasal, Sukabumi :

Politea Bogor.

Viswandoro (2014), Kamus Istilah

Hukum, Sumber Rujukan

Peristilahan Hukum, Jakarta :

Penerbit Pustaka Yustisia. 